УДК 378.018.43:004]:005.6

DOI: $\underline{10.35619 / \text { iiu.v2i13.386 }}$

\author{
Стеблецький Анатолій \\ кандидат педагогічних наук, доцент, \\ доцент кафедри теорії та історії педагогіки \\ педагогічного інституту \\ Київського університету імені Бориса Грінченка, \\ м. Київ, Україна \\ ORCID: 0000-0001-7445-9947 \\ e-mail: a.stebletskyi@kubg.edu.ua
}

\title{
ЧИННИКИ ЗАБЕЗПЕЧЕННЯ ЯКОСТІ ВИЩОЇ ОСВІТИ В УМОВАХ ОНЛАЙН НАВЧАННЯ
}

Анотація. У статті закцентовано увагу на спрямованості професійної діяльності науково-педагогічних працівників закладу вищої освіти (3ВО) в умовах онлайн навчання. На основі проведеного дослідження сформульовано протиріччя, що виникли між традиційним методичним супроводом освітнього процесу і забезпеченням високої якості освітніх послуг в умовах карантинних заходів. Охарактеризовано сучасний освітній процес, який стає все більше недирективним і потребує, з боку викладача, фасилітаційного супроводу, а освітня діяльність набуває характеру самоорганізованого i автономно розвивального процесу в умовах постійних змін. Визначено чинники, резерви забезпечення успішності взаємодії суб'єктів освітнього процесу щодо досягнення прогнозованих результатів навчання. Проаналізовано проблему забезпечення ефективним методичним супроводом освітнього процесу закладу вищої освіти в умовах онлайн навчання. Схарактеризовано основні тенденції і перспективи розвитку онлайн навчання у вищій школі.

Розглянуто сутність університетського середовища (різноманітні контакти, враження, досвід навчальних і особистісних ситуацій), яка лежить в основі оволодіння обраною спеціальністю. Визначено віртуальне освітнє середовище як допоміжний чинник забезпечення якості вищої освіти.

На основі проведено дослідження сформульовано пропозиції щодо забезпечення якості вищої освіти в умовах онлайн навчання.

Ключові слова: онлайн навчання, освітня діяльність, результати навчання, суб'єкти освітнього процесу, чинники забезпечення якості вищої освіти, якість вищої освіти.

Постановка проблеми. Якість вищої освіти $є$ складною сферою для аналізу. Вона відображається через особистісні смисли, які має освіта для суб'єктів, освітні стандарти, професіоналізм науково-педагогічних 


\section{Інноватика у вихованні. Випуск 13.Том 2. 2021.}

працівників, сучасні освітні технології та засоби навчання, ефективність освітнього менеджменту та фінансування.

Якість вищої освіти - відповідність умов провадження освітньої діяльності та результатів навчання вимогам законодавства та стандартам вищої освіти, професійним та/або міжнародним стандартам (за наявності), а також потребам заінтересованих сторін і суспільства, що забезпечується шляхом здійснення процедур внутрішнього та зовнішнього забезпечення якості (Закон України «Про вищу освіту», 2014). Н. Г. Батечко визначає якість освіти як складну систему, яка поєднує організаційну структуру, методики, процеси і ресурси необхідні для функціонування системи освіти 3 метою іiі відповідності соціальним нормам та державним освітнім стандартам (Батечко, 2017).

В умовах сьогодення вагомості набуває онлайн навчання у закладах освіти. Забезпечення якості вищої освіти в умовах онлайн навчання $€$ насущною проблемою освітян. У цій статті викладено результати нашого дослідження щодо цієї проблеми.

Аналіз останніх досліджень 3 проблеми. Важливий чинник, що забезпечує якість вищої освіти - професійна діяльність науковопедагогічних працівників. Суб'єкти освітнього процесу закладу вищої освіти досягають спільних цілей у взаємодії, яка має різні аспекти: комунікативний, інтелектуальний, мовленнєвий, етичний, емоційний, діяльнісний.

Українські дослідниці Н. Хворостяна, М. Вєлікжаніна визначили такі чинники забезпечення якості освіти: професійна підготовка суб'єктів викладання, їхні особистісні якості; навчально-методичне забезпечення процесу підготовки; наявність системи контролю й оцінювання викладання, рівня знань суб'єктів учіння, що відповідає сучасним вимогам; застосування викладачами вищої школи сучасних освітніх технологій; навчання на дослідницькій основі; відповідність програм навчальних дисциплін сучасним вимогам; контакти 3 провідними іноземними фахівцями; належне матеріально-технічне забезпечення освітнього процесу; забезпеченість науковою літературою освітніх закладів; спрямованість викладання на формування соціальних якостей сучасного фахівця тощо (Хворостяна та Вєлікжаніна, 2012). У контексті дослідження щодо забезпечення якості вищої освіти в умовах онлайн навчання ми розглянемо лише деякі з них.

Важливі аспекти створення умов забезпечення якості вищої освіти досліджували $\quad$ Н. Г. Батечко, М. В. Братко, І. Ю. Мальований, О. Я. Савченко, С. О. Сисоєва, Л. Л. Хоружа та інші. Використання цифрових засобів та інформаційно-комунікативних технологій в умовах онлайн навчання представлено в працях О. П. Буйницької, І. В. Іванюк, О. В. Овчарук, В. В. Осадчого, Н. В. Морзе та ін. Важливі питання формування і функціонування віртуальних освітніх середовищ знайшли відображення у наукових роботах В. Ю. Бикова,
М. В. Братко,
Н. В. Морзе,
О. О. Лаврентьєвої,
К. П. Осадчої, 


\section{Інноватика у вихованні. Випуск 13.Том 2. 2021.}

В. В. Прошкіна та ін. Попри велику кількість наукових доробків, проблема забезпечення якості вищої освіти в умовах онлайн навчання потребує подальших досліджень.

Мета статті - визначити чинники, що забезпечать досягнення прогнозованих результатів навчання, в умовах онлайн навчання.

Завдання статті полягають у визначенні резервів забезпечення якості вищої освіти в умовах онлайн навчання, що впливають на успішність взаємодії суб'єктів освітнього процесу щодо забезпечення прогнозованих результатів навчання здобувачів і сформульовано протиріччя, що виникли між традиційними методичним супроводом освітнього процесу (3BO) i необхідністю забезпечення якості вищої освіти в умовах онлайн навчання.

Виклад основного матеріалу дослідження. В умовах карантинних заходів навчання у закладах вищої освіти відбувається в режимі онлайн. Студенти оволодівають фахом віддалено від навчального закладу.

У недалекій перспективі десятки закладів вищої освіти України будуть пропонувати дистанційну освіту, яка має як позитивні, так i негативні особливості в порівнянні з традиційними формами:

наявність застарілого технічного обладнання у викладачів і студентів, що має низьку продуктивність і не дозволяє працювати на онлайн занятті;

складність організації онлайн навчання 3 використанням нових інформаційно-комунікаційних технологій та Інтернет-сервісів, які ще не можуть у повній мірі задовольнити запити освітян;

проблема ідентифікації особистості здобувача щодо самостійності виконання завдань;

труднощі в організації спільних видів навчальної діяльності, оптимальної взаємодії викладача та здобувачів вищої освіти (синхронізація, сумісність технічна і програмна);

обмеженість основних Інтернет ресурсів і сервісів як інструментів на онлайн заняттях.

Кількість накопичених змін у вищій освіті, особливо в умовах карантинних заходів, суттєво зросла, їх системне врахування стає складним, а управління освітнім процесом стає все менш ефективним, мало піддається цілеспрямованій трансформації. В умовах онлайн навчання у більшій мірі затребувані функції викладача як консультанта, фасилітатора, коуча, менеджера навчального електронного курсу (ЕНК) та проведення онлайн занять, педагогічного дизайнера ЕНК, аніматора, що має на меті активізувати пізнавальну активність присутніх на онлайн занятті. Він формує у студентів впевненість у власних силах, віру у здатність вирішувати задачі конструктивною позицією, відповідними ій поглядами та діями, позитивними емоціями у навчальній взаємодії (здивування, радість, симпатію, переживання успіху, готовністю до компромісу, співпраці) (Дауні, 2008). Педагог тренує вміння напрацьовувати можливі варіанти розв'язання завдань в кейсах, проєктах, що суттєво підвищує показники швидкості, гнучкості та оригінальності мислення. Він усіляко стимулює прагнення студента до самостійного 


\section{Інноватика у вихованні. Випуск 13.Том 2. 2021.}

вибору цілей, задач і засобів їхнього вирішення. Ми вважаємо, що освітній процес у вищій школі має тенденцію переходу до іншої освітньої парадигми. Її сутність полягає у тому, що освіта майбутнього фахівця стає процесом недирективним, iз фасилітаційним супроводом, а освітня діяльність - самоорганізованим і автономно розвивальним процесом в умовах постійних змін.

Досвід проведення онлайн занять спонукав нас шукати нові підходи до викладання, до думки про те, що потрібна інша культура взаємодії в системі викладач-студенти, яка б грунтувалася на принципах, що характеризуються такими поняттями як «відкритість», «неупередженість», «доброзичливість», «відповідальність», «професійна рефлексія», «педагогічна імпровізація». До того ж всі учасники освітнього процесу на достатньому рівні повинні вміти користуватись сучасними Інтернетплатформами та ресурсами, технічними засобами. Погляд на суб'єктів освітнього процесу теж потребує уточнення.

Вважаємо, що система «викладач-студенти» $\epsilon$ відкритою, саморозвивальною і нелінійною системою. Відкрита система - це система, яка взаємодіє 3 навколишнім середовищем. Нелінійна система характеризується складністю передбачення результату впливу на неї, напрямку ï розвитку. Розвиток розглядаємо як закономірне чергування станів нерівноважності й рівноваги. Кожен стан має свої можливості, які варто враховувати для реалізації освітніх цілей. Його неможливо прогнозувати, як пряму залежність від педагогічних впливів, кількості залучених засобів і виховних зусиль. Нерівноважність системи «викладачстуденти» виникає, коли викладач безпосередньо не впливає на навчальну роботу студентів (здобувачі вищої освіти самостійно виконують завдання, взаємодіють у навчальних групах тощо). Цей стан системи (нерівноважність) дає студентам ступені свободи: виконати завдання самостійно, звернутись за допомогою до товариша чи до викладача. Таким чином, система «викладач-студенти» не обов'язково підтримується прагненням до взаємодії як з боку науково-педагогічного працівника, так і здобувача, що й робить іiі нестійкою. Саме у стані нерівноважності відбувається розвиток студентів, які виконують завдання, спрямовані на утворення бажаних освітніх патернів, які будуть закріплені ними як складові відповідної компетентності, на етапі самоорганізації й рівноваги системи «викладач-студенти». Стійкість системи досягається спільним прагненням до співпраці, а відтак - до рівноваги, яку необхідно підтримувати суб'єктам освітнього процесу, без цього не буде конструктивної взаємодії.

Із шкільних та студентських років ми пам'ятаємо вчителів i викладачів за їх вчинками. Чому вони закарбувалися в нашу пам'ять? Ми вважаємо, що такий ефект може бути досягнутий за умов цілісності сприймання педагогічного впливу, його особистісного спрямовання. Важливо, щоб взаємодія суб'єктів освітнього процесу характеризувалась доброзичливістю, відкритістю, неупередженістю, готовністю до 


\section{Інноватика у вихованні. Випуск 13.Том 2. 2021.}

конструктивного діалогу, силою впливу особистості педагога на учня у відповідній ситуації. Поступово, накопичуються зміни в особистості здобувача освіти, які не можна прорахувати жодним комп'ютером, адже вони проявляються в трансформації особистісних якостей, поглядів, переконань, як результат змінюється поведінка, спрямування особистісних учинків. У цьому випадку вирішальну роль відіграє готовність учня зробити відповідний висновок і сила враження, яку справив на нього педагог. Результат такої взаємодії схожий на описаний в науковій літературі «ефект метелика» (поняття ввів американський математик i метеоролог Е. Лоренц). Сутність цього феномену полягає у тому, що незначні зміни, що відбуваються в нелінійній нестійкій системі, можуть привести до яких завгодно великих і непередбачуваних наслідків у майбутньому (Селівестрова, 2019).

Суб'єкта розглядаємо як складну, нелінійну систему, яка періодично, із невизначеним періодом, може бути стійкою або нестійкою, в залежності від різноманітних чинників (обставин). Одні стабілізують суб'єкта, а інші - навпаки виводять із рівноваги. Але все це $є$ невід'ємними етапами розвитку здобувача освіти, становлення його особистості. Одним із важливих результатів здобуття освіти суб'єктом $є$ досягнення прогнозованого результату навчання.

Результати навчання - знання, уміння, навички, способи мислення, погляди, цінності, інші особистісні якості, набуті у процесі навчання, виховання та розвитку, які можна ідентифікувати, спланувати, оцінити i виміряти та які особа здатна продемонструвати після завершення освітньої програми або окремих освітніх компонентів (Закон України «Про освіту», 2017).

Для забезпечення високих результатів навчання студентів в умовах онлайн навчання варто звернути увагу на чинники, що заважають їх досягненню.

У нашому дослідженні брали участь студенти другого та п'ятого курсів. Першими відтворюємо результати відповідей студентів п'ятого курсу, а наступними - другого.

Я маю все необхідне технічне забезпечення для навчання онлайн.

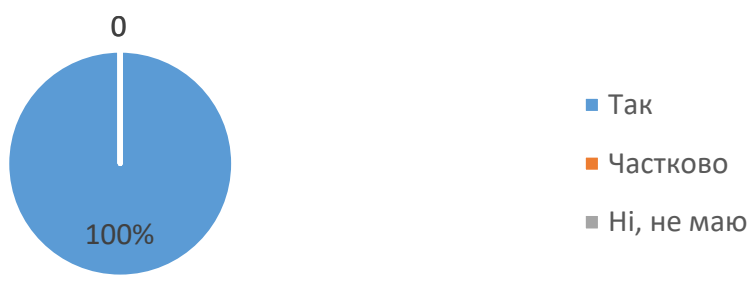




\section{Інноватика у вихованні. Випуск 13.Том 2. 2021.}

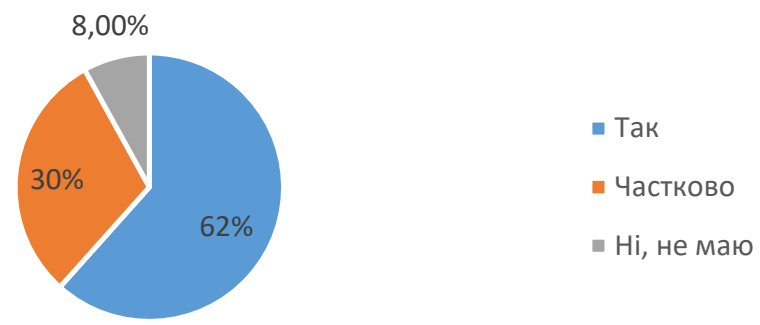

Технічне забезпечення для онлайн навчання студентів знаходиться на рівні близько $75 \%$, причому чим старший курс, тим ближчий цей показник до 100\%. Це свідчить про зростання відповідальності здобувачів освіти і вмотивованості у забезпеченні себе необхідними засобами навчання.

Я вмію користуватися всіма електронними ресурсами, що використовують викладачі в навчальному процесі.

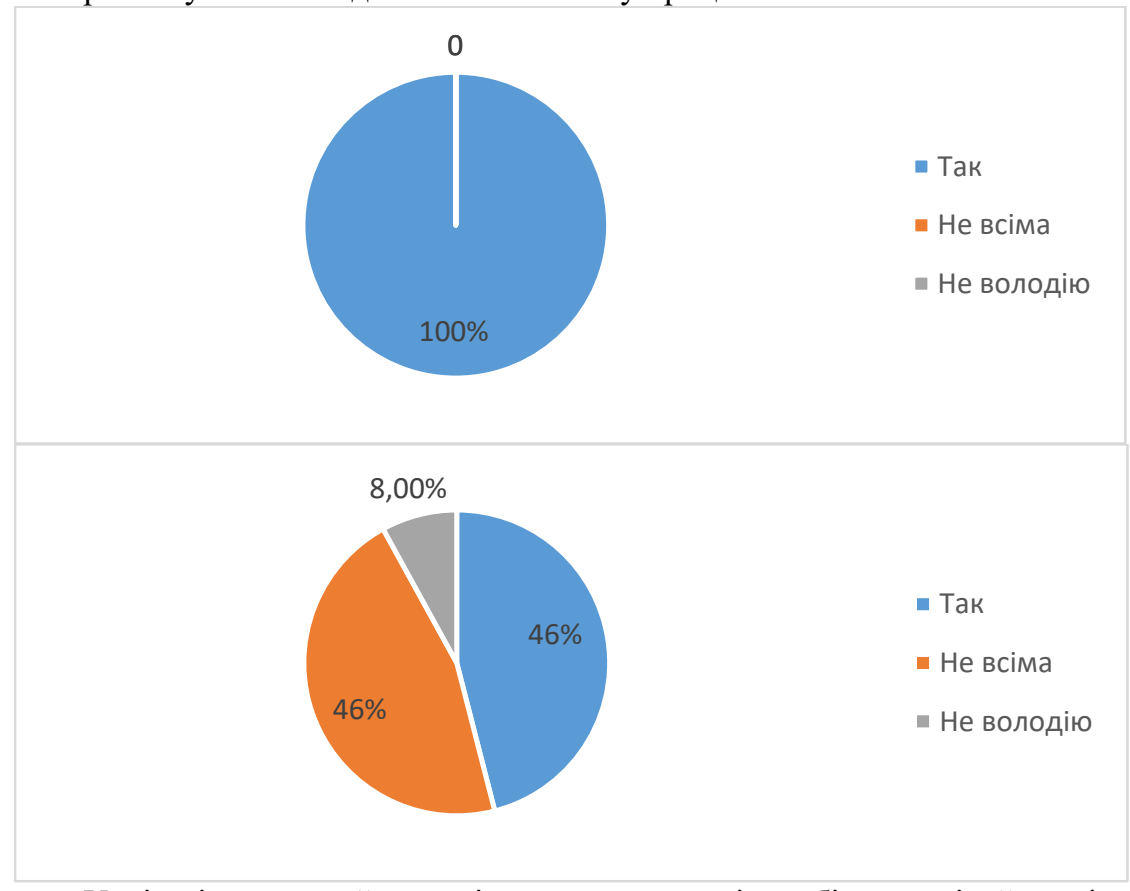

Успішність онлайн освіти залежить від обізнаності й умінь використовувати інтернет-ресурси, платформи та інші онлайн засоби навчання суб'єктами освітнього процесу. Середній відсоток здобувачів вищої освіти, які без особливих труднощів застосовують весь арсенал інтернет-ресурсів становить $65 \%$. Серед здобувачів п'ятого курсу таких $100 \%$, серед здобувачів другого курсу $-46 \%$.

Електронні курси навчальних дисциплін використовую 


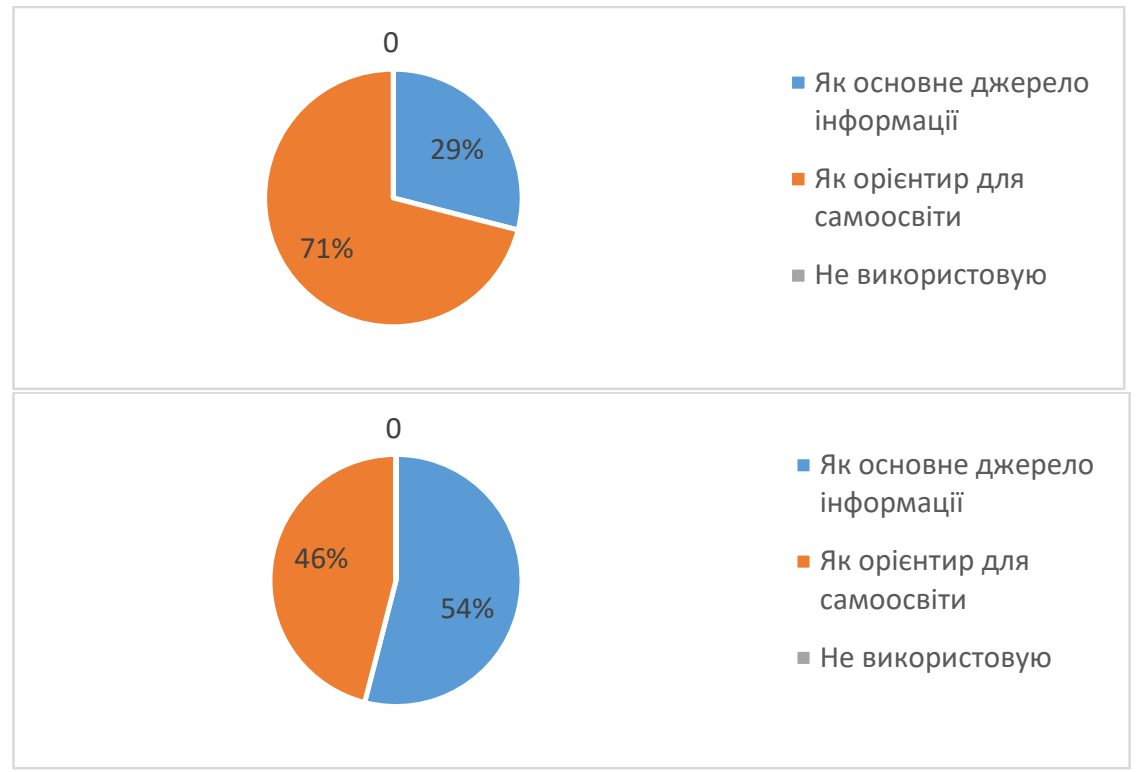

$71 \%$ здобувачів пятого курсу i $46 \%$ здобувачів другого курсу використовують матеріали 3 електронних навчальних курсів (ЕНК) як орієнтир для самоосвіти. Ми вважаємо, що при розробці ЕНК для студентів бакалаврату варто закцентувати увагу на мотивацію до самоосвіти і самостійності у пошуку навчальної інформації, а також передбачити варіативність завданнь для самостійної роботи.

Результатами свого навчання онлайн

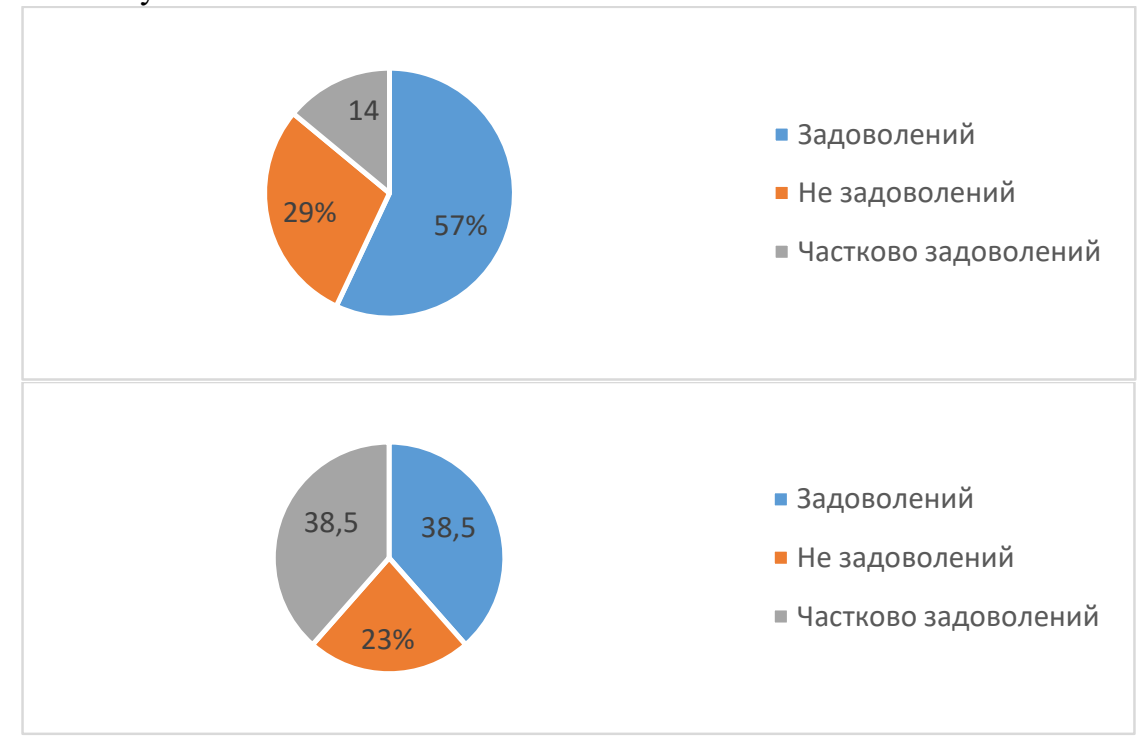




\section{Інноватика у вихованні. Випуск 13.Том 2. 2021.}

Оволодіння способами, засобами навчання сприяє зростанню самостійності і відповідальності здобувачів у процесі виконання різних завдань. Результатами свого навчання задоволені $57 \%$ у студентів п'ятого курсу і 38,5\% у - другого.

Для забезпечення успішності навчання здобувачів ми враховуємо те, що процес формування вмінь і навичок визначається не кількістю вправ, а його організацією як активної, цілеспрямованої діяльності суб'єкта. Водночас суттєвий вплив мають умови, у яких виникає потреба пошуку орієнтирів i можливість їх виокремлення, порівняння отриманих результатів з еталонними (Ситніков, 1996).

Проблеми забезпечення якості вищої освіти в умовах онлайн навчання:

утримувати увагу слухачів, які знаходяться не в одній аудиторії 3 лектором, досить складно;

домашні умови не завжди сприяють зосередженій роботі на занятті;

не всі учасники освітнього процесу можуть скористатись інтернетсервісами в силу об'єктивних і суб'єктивних причин;

інструментів, які можна використати в одному інтернет-ресурсі часто недостатньо для досягнення освітніх цілей, тому доводиться переключатись, що знижує темп заняття;

у системі Moodle виявлено огріхи підготовлених онлайн курсів (розрахованих для офлайн навчання).

формування мотивації до навчання в режимі онлайн, труднощі онлайн комунікації.

Висновок і перспективи подальших розвідок. На нашу думку, варто спрямувати зусилля науково-педагогічної спільноти на обгрунтування і створення ефективних освітніх технологій в умовах онлайн навчання, які б забезпечували високий рівень узгодженості навчальної діяльності суб’єктів освітнього процесу, оптимізації їх співпраці, досягненню прогнозованих результатів навчання.

Онлайн навчання продовжує прискорено розвиватись. Набуває поширення освітній аутсорсинг - заміна частини навчальних курсів матеріалами інших розробників; прискорене введення технологій дистанційного навчання в освітній процес. Дистанційна форма навчання може набути чинності. Це може зруйнувати університет як соціальний інститут, на місце якого прийде бізнес-структура мережевого типу, що буде функціонувати лише як онлайн освітній заклад. Щоб уникнути цього варто зберігати офлайн навчання воно дорожче, ніж дистанційне, яке на відміну від онлайн має багато переваг: безпосередній контакт суб'єктів освітнього процесу, забезпечення вищої якості освітніх послуг, практичні заняття, в спеціально облаштованих аудиторіях, оволодіння практичними навичками в процесі демонстрації, ілюстрації процесів, предметів у їх натуральному вигляді, наприклад, лікувальний масаж. Поширення хмарних технологій, електронного та дистанційного навчання, складання репозиторіїв електронних ресурсів, а також розробка моделі оцінювання 


\section{Інноватика у вихованні. Випуск 13.Том 2. 2021.}

стану інформатизації навчальних закладів $\epsilon$ одним із чинників забезпечення якості вищої освіти в умовах онлайн навчання (Осадчий, Осадча, 2015). На нашу думку, закладам вищої освіти варто зосередяться на освітніх задачах, які не в змозі вирішити жодна онлайн-платформа чи дистанційна форма навчання. Загальновідомо що, цифрові технології суттєво відстають у розвитку «м'яких навичок»; спілкування і взаємодія не сильні сторони цифрових технологій. Віртуальні освітні середовища не замінять реальні об'єкти, взаємодія 3 якими $є$ необхідною умовою оволодіння обраною спеціальністю. Університетське середовище - це різноманітні контакти, враження, досвід навчальних i особистісних ситуацій, воно впливає на формування важливих компетенцій для успішності випускника у професійної діяльності. Віртуальне освітнє середовище - допоміжний чинник забезпечення якості вищої освіти.

Ми підтримуємо пропозиції науковців С. О. Сисоєвої, В. В. Осадчого, К. П. Осадчої щодо залучення до освітнього процесу університетів фахівців нових професій, наприклад, консультанта онлайн-навчання, педагогічного дизайнера, тьютора тощо (Сисоєва, Осадчий та Осадча, 2011). Це потрібно для того, щоб формувати спільно із здобувачем його індивідуальну освітню траєкторію із вибором видів, форм, освітніх компонентів і темпу здобуття освіти та формування відповідальності за вибір цих траєкторій, результати навчання.

\section{СПИСОК ВИКОРИСТАНИХ ДЖЕРЕЛ}

Міністерство освіти і науки України, (2014). Закон Украӥни «Про вищу освіту»; URL: https://zakon.rada.gov.ua/laws/show/1556-18\#Text. [Дата звернення 14.05.21].

Міністерство освіти і науки України, (2017). Закон України «Про освіту»; URL: https://zakon.rada.gov.ua/laws/show/2145-19\#Text. [Дата звернення 24.04.21].

Батечко, Н. (2017). Феномен якості вищої освіти в сучасному науковому дискурсі. Освітологічний дискурс. № 3-4, с. 1-16.

Хворостяна, Н. та Вєлікжаніна, М. (2012) Аналіз основних чинників, які забезпечують якість освіти. Економіка $і$ регіон. № 3 (34). П: ПНТУ. CC. 25-29.

Дауни, М. (2008). Эффективный коучинг: Уроки коуча коучей. М.: «Добрая книга», 288 с.

Селиверстова, А. (2019). Теория динамического хаоса в исследованиях социально-философской и социальной направленности. Том 22, № 2, 2019 Южноукраинский национальный педагогический университет имени К. Д. Ушинского URL: https://core.ac.uk/download/pdf/268619724.pdf. [Дата звернення 24.04.21].

Ситников, А. (1996). Акмеологический тренинг: Теория. Методика. Психотехнологии. М.: Технологическая школа бизнеса. СС. 28-29.

Осадчий, В. та Осадча, К. (2015). Сучасні реалії і тенденції розвитку інформаційно-комунікаційних технологій в освіті. Інформаційні 


\section{Інноватика у вихованні. Випуск 13.Том 2. 2021.}

технологіï $i$ засоби навчання. Т. 48, вип. 4, с. 47-57. URL: http://nbuv.gov.ua/UJRN/ITZN_2015_48_4_6. [Дата звернення 05.05.21].

Сисоєва, С., Осадчий В., Осадча К. (2011). Професійна підготовка викладача-тьютора: теорія і методика. К.: Видавничий будинок ММД. $280 \mathrm{c}$.

\section{REFERENCES}

Ministerstvo osvity i nauky Ukrainy, (2014). Zakon Ukrainy "Pro vyshchu osvitu" [Law of Ukraine "On Higher Education"]; URL: https://zakon.rada.gov.ua/laws/show/1556-18\#Text. [Data zvernennia 14.05.21].

Ministerstvo osvity i nauky Ukrainy, (2017). Zakon Ukrainy "Pro osvitu" [Law of Ukraine "On Education"]; URL: https: //zakon.rada.gov.ua/laws/show/2145-19\#Text. [Data zvernennia 24.04.21].

Batechko, N. (2017). Fenomen yakosti vyshchoi osvity $v$ suchasnomu naukovomu dyskursi [The phenomenon of quality of higher education in modern scientific discourse]. Osvitolohichnyi dyskurs. No 3-4. SS. 1-16.

Khvorostiana, H. \& Vielikzhanina, M. (2012) Analiz osnovnykh chynnykiv, yaki zabezpechuiut yakist osvity [Analysis of the main factors that ensure the quality of education]. Ekonomika i rehion. No 3 (34). Poltava: PNTU. SS. 25-29.

Dauni, M. (2008). Effektivnyi kouching: Uroki koucha kouchei [Effective Coaching: Lessons from a Coach by Coaches]. M.: "Dobraya kniga". $288 \mathrm{~s}$.

Seliverstova, A. (2019). Teoriya dinamicheskogo khaosa $v$ issledovaniakh sotsialno-filosofskoi $i$ sotsialnoi napravlennosti [The theory of dynamic chaos in studies of socio-philosophical and social orientation]. Tom 22, No 2. 2019 Yuzhnoukrainskiy natsyonalnyi pedagogicheskiy universitet imeni K. D. Ushynskogo; URL: https://core.ac.uk/download/pdf/268619724.pdf. [Data zvernennia 24.04.21].

Sitnikov, A. (1996). Akmeologicheskiy trening: Teoriya. Metodika. Psikhotekhnologii [Acmeological training: Theory. Methodology. Psychotechnology.]. M.: Tekhnologicheskaya shkola biznesa. SS. 28-29.

Osadchyi, V., Osadcha, K. (2015). Suchasni realii i tendentsii rozvytku informatsiino-komunikatsiinykh tekhnolohii $v$ osviti. Informatsiini tekhnolohii $i$ zasoby navchannia [Modern realities and trends in the development of information and communication technologies in education]. T. 48, vyp. 4, - s. 47-57. URL: http://nbuv.gov.ua/UJRN/ITZN_2015_48_4_6 [Data zvernennia 05.05.21].

Sysoieva, S., Osadchyi V. \& Osadcha K. (2011). Profesiina pidgotovka vykladacha-tiutora: teoriia i metodyka [Professional training of a tutor: theory and methodology]. K.: Vydavnychyi budynok MMD. $280 \mathrm{~s}$. 


\title{
FACTORS OF QUALITY ASSURANCE OF HIGHER EDUCATION IN THE CONDITIONS OF ONLINE LEARNING
}

\author{
Anatoliy Stebletskyi \\ Candidate of Pedagogical Sciences, Associate Professor, \\ Associate Professor at Theory and History of Pedagogy Department \\ Pedagogical Institute of \\ Borys Hrinchenko Kyiv University, \\ Kyiv, Ukraine \\ ORCID: 0000-0001-7445-9947 \\ e-mail: a.stebletskyi@kubg.edu.ua
}

\begin{abstract}
Economic and social changes, the demise emergence of professions create new, rapid and, therefore, not always successful transformation processes in education. The problem of quality assurance of education has always been and remains topical till nowadays. This problem has become especially acute during the transition of the educational process to online mode. Therefore, everything related to maintaining high standards of educational services by higher education institutions (HEIs) under the quarantine restrictions requires scientific analysis. This has determined the purpose of the present study. The article deals with the factors of higher education quality assurance in the context of online learning. The factors influencing the success of interaction of the educational process parties to ensure the trainees' projected learning outcomes have been identified.

Reserves for ensuring the quality of higher education under the online learning conditions have been determined, one of them being the purposeful development of interaction between the parties to the educational process on the basis of openness, impartiality, friendliness, responsibility, integrity, constructiveness, perfection. On the basis of the conducted research, the contradictions arisen between the existing methodical support of educational process and necessity of maintenance of higher education quality under the conditions of online training have been formulated and considered. The factors influencing the success of trainees in the process of learning at higher educational institutions in the conditions of online learning, as well as those hindering the achievement of the predicted learning outcomes have been analyzed. Conditions for the development of interaction of the parties to the educational process are determined by the interdependence of the processes that are the basis of their educational activities self-organization. In the conditions of online learning, the direction of professional activity of scientific and pedagogical employees at higher educational institutions changes and becomes more advanced, the educational process becomes after all more and more nondirective and needs facilitation support on behalf of the teacher. Educational activity acquires the properties of self-organized and autonomously developing process under the conditions of continual changes. The analysis of problems in providing effective methodical support of the educational process at the higher
\end{abstract}




\section{Інноватика у вихованні. Випуск 13.Том 2. 2021.}

education institution under the conditions of online learning format has been carried out. The main trends and prospects for the development of online learning in higher education have been characterized.

Keywords: online learning, educational activities, learning outcomes, subjects of the educational process, factors of quality assurance of higher education, the quality of higher education.

Стаття надійшла до редакиії 20.04.2021 p. 